\title{
Contents and yields of copper, iron, manganese and zinc would be affected by lucerne age and cut
}

\author{
Zhennan Wang ${ }^{\text {Corresp., } 1}$, Yizhao Shen ${ }^{2}$, Chongliang Bi ${ }^{1}$, Mirielle Pauline ${ }^{3}$, Qingping Zhang ${ }^{1}$, Shenjin Lv ${ }^{1}$, Huimin \\ Yang ${ }^{\text {Corresp., }}{ }^{4}$, Yan Yang ${ }^{5}$ \\ ${ }^{1}$ College of Agriculture and Forestry Sciences, Linyi University, Linyi, China \\ 2 College of animal science and technology, Hebei Agricultural University, Baoding, China \\ 3 Department of Pediatrics, University of Alberta, Edmonton, Canada \\ 4 State Key Laboratory of Grassland Agro-ecosystems, College of Pastoral Agriculture Science and Technology, Lanzhou University, Lanzhou, China \\ 5 Linyi academy of agricultural sciences, Linyi, China \\ Corresponding Authors: Zhennan Wang, Huimin Yang \\ Email address: wangzhennan@lyu.edu.cn, huimyang@|zu.edu.cn
}

Background. Lucerne is a perennial legume forage, which can produce multiple cuts in one year. Microelements play fundamental roles in the function, maintenance and adaptation to the environment for lucerne growth. However, it is unknown previously on the accumulation of copper ( $\mathrm{Cu})$, iron (Fe), manganese $(\mathrm{Mn})$ and Zinc $(\mathrm{Zn})$, which vary with lucerne ages or cuts. Therefore, a hypothesis on the $\mathrm{Cu}, \mathrm{Fe}, \mathrm{Mn}$ and $\mathrm{Zn}$ in lucerne varying with age and cut, was tested. Methods. 11, 8, 5, 4 and 1 year old lucerne (Medicago sativa Longdong) were selected as the material (until 2012 year), and samples were taken as three cuts at the cutting periods (early flowering stage) in 2012. Then, the contents and yields of $\mathrm{Cu}, \mathrm{Fe}, \mathrm{Mn}$ and $\mathrm{Zn}$ in lucerne were measured and calculated. Results. The highest contents of $\mathrm{Cu}, \mathrm{Fe}, \mathrm{Mn}$ and $\mathrm{Zn}$ in lucerne were found in the 1 year old among the five ages, at the $3^{\text {rd }}$ cut compared to the other two cuts, and in the leaf among the three organs. The highest yields of $\mathrm{Cu}, \mathrm{Fe}, \mathrm{Mn}$ and $\mathrm{Zn}$ were found in the older ages (11 and 8 years old), at the $3^{\text {rd }}$ cut, and in the root among the three organs. The most positive correlations were found between contents, yields and biomass. Conclusions. The hypothesis was supported by the results. And the contents and yields of lucerne $\mathrm{Cu}, \mathrm{Fe}, \mathrm{Mn}$ and $\mathrm{Zn}$ were affected by the age, cut and organ. Furthermore, the yields of lucerne $\mathrm{Cu}, \mathrm{Fe}$, $\mathrm{Mn}$ and $\mathrm{Zn}$ were determined by their contents and lucerne biomass. 
1 Contents and yields of copper, iron, manganese and zinc would be affected by

4 Zhennan Wang ${ }^{* 1}$, Yizhao Shen ${ }^{2}$, Chongliang $\mathrm{Bi}^{1}$, Mirielle Pauline ${ }^{3}$, Qingping Zhang ${ }^{1}$, Shenjin $\mathrm{Lv}^{1}$, Huimin 5 Yang $^{* 4}$, Yan Yang 5

71 College of Agriculture and Forestry Sciences, Linyi University, Linyi 276000, China;

82 College of Animal Science and Technology, Hebei Agricultural University, Baoding 071001, Hebei Province, 9 China;

103 Department of Pediatrics, University of Alberta, Edmonton, Alberta T6G 2R3, Canada;

114 State Key Laboratory of Grassland Agro-ecosystems, College of Pastoral Agriculture Science and Technology, 12 Lanzhou University, Lanzhou 730020, China;

135 Linyi Academy of Agricultural Sciences, Linyi 276012, China

14 *Corresponding authors:

15 Zhennan Wang*1

16 College of Agriculture and Forestry Sciences, Linyi University, Linyi 276000, China. Tel: 00865398766317.

17 Email address: wangzhennan@1yu.edu.cn

Huimin Yang*4

State Key Laboratory of Grassland Agro-ecosystems, College of Pastoral Agriculture Science and Technology, 


\section{Abstract}

Background. Lucerne is a perennial legume forage, which can produce multiple cuts in one year. Microelements play fundamental roles in the function, maintenance and adaptation to the environment for lucerne growth. However, it is unknown previously on the accumulation of copper $(\mathrm{Cu})$, iron $(\mathrm{Fe})$, manganese $(\mathrm{Mn})$ and Zinc $(\mathrm{Zn})$, which vary with lucerne ages or cuts. Therefore, a hypothesis on the $\mathrm{Cu}, \mathrm{Fe}, \mathrm{Mn}$ and $\mathrm{Zn}$ in lucerne varying with age and cut, was tested.

Methods. 11, 8, 5, 4 and 1 year old lucerne (Medicago sativa Longdong) were selected as the material (until 2012 year), and samples were taken as three cuts at the cutting periods (early flowering stage) in 2012. Then, the contents and yields of $\mathrm{Cu}, \mathrm{Fe}, \mathrm{Mn}$ and $\mathrm{Zn}$ in lucerne were measured and calculated.

Results. The highest contents of $\mathrm{Cu}, \mathrm{Fe}, \mathrm{Mn}$ and $\mathrm{Zn}$ in lucerne were found in the 1 year old among the five ages, at the $3^{\text {rd }}$ cut compared to the other two cuts, and in the leaf among the three organs. The highest yields of $\mathrm{Cu}$, $\mathrm{Fe}, \mathrm{Mn}$ and $\mathrm{Zn}$ were found in the older ages (11 and 8 years old), at the $3^{\text {rd }}$ cut, and in the root among the three organs. The most positive correlations were found between contents, yields and biomass.

Conclusions. The hypothesis was supported by the results. And the contents and yields of lucerne $\mathrm{Cu}, \mathrm{Fe}, \mathrm{Mn}$ and $\mathrm{Zn}$ were affected by the age, cut and organ. Furthermore, the yields of lucerne $\mathrm{Cu}, \mathrm{Fe}, \mathrm{Mn}$ and $\mathrm{Zn}$ were determined by their contents and lucerne biomass.

Keywords: age, cut, organ, Medicago sativa, trace element

\section{Introduction}

Nutrient elements in plants play a basic role during their growth and adaptation to the environment (Wright \& Westoby, 2003; Imaran \& Gurmani, 2011; Kováčik \& Škarpa, 2019). Generally, carbon content increases (Marković et al., 2009), and mineral nutrient (macroelements \& microelements) contents are gradually diluted as the plant grows (Tyrolova \&Výborna, 2008; Marković et al., 2009; Yang \& Luo, 2011). But their accumulations would increase as the plant biomass increased(Hooker \& Compton, 2003). These changes were generally observed in some annual plants or in some perennial plants within one cut or a growing season. However, the element contents change more complexly due to a longer lifetime and frequent use annually for the perennial plant(Wang et al., 2015; Akburak, 2020). Thus, exploring how element contents change with plant age or growing season are important to better understand the adaptation of a perennial plants to the environment.

Similar to macroelements, microelements are also needed for plant growth(Marković et al., 2009; Lukin et al., 2018). They are the components and prosthetic groups of many enzymes, and would lead to a high plant yield and high chemical constituents (such as carbohydrates, protein, oil)(EISayed et al., 2018; Afsahi et al., 2020; Ierna et al.,2020). Adversely, when plants lack a microelement, young leaves and stems will have limited growth with yellowing leaves, the plant withering, the leaves falling off, and the leaves having mottled spots (Imran \& Gurmani, 2011; Lu et al.,2020). Furthermore, the nutrient-deficient plant as forage are fed to livestock which could experience a range of dietary mineral imbalances unless supplementary mineral sources are provided (Raeside, Nie \& Behrendt, 2012; Kletikova et al., 2019). Correctly aligned phase nutrition program minimizes metabolic problems of livestocks(Skalicka et al., 2016). Livestock also choose initiatively to eat the fodder with the highest concentrations of plant microelements (such as $\mathrm{Cu}$ and $\mathrm{Zn}$ ) for their advantage(Azuma et al., 2016). Thus neglecting the microelements in plants not only negatively limits plant growth, but also negatively affects the health of livestock. 
Lucerne is a kind of perennial legume forage with an average lifespan that exceeds 20 years (Bennett, 2012), has been cultivated almost 32 million hectare in the world and 1300 thousands hectare in China, and it is continually cultivating more in recent years. It was domesticated as early as $7000 \mathrm{BCE}$, and it originated from Central Aisa (Torabi et al., 2011). In China, lucerne has more than 2000 years of planting history. It is used as widespread forage with a high nutritional (include protein and amino acid et al.) (Caunii et al., 2012), economic and environmental protection values (Li \& Huang, 2008). But the forage yield of lucerne decreases with increasing age, and Li \& Huang (2008) suggested that lucerne should be utilized at more than 8 years old which was estimated by the comprehensive results of forage yield and soil water. And Wang et al. (2015) also suggested to apply optimal $\mathrm{N}$ fertilization to the stands of 8 years or older lucerne for the persistence of lucerne production which was estimated by the macroelements (i.e. $\mathrm{N}$ and $\mathrm{P}$ ). The age-effect of microelements is often neglected.

In this study, we tested four microelements, i.e. copper $(\mathrm{Cu})$, iron $(\mathrm{Fe})$, manganese $(\mathrm{Mn})$ and zinc $(\mathrm{Zn})$. The hypothesis was that $\mathrm{Cu}, \mathrm{Fe}, \mathrm{Mn}$ and $\mathrm{Zn}$ could change with stand age and cut of lucerne. The specific objectives were to find out: (1) How the contents of $\mathrm{Cu}, \mathrm{Zn}, \mathrm{Mn}$ and $\mathrm{Zn}$ differ among stand ages and cuts of lucerne; and (2) what are the relationships of the contents and yields of the four microelements in lucerne.

\section{Materials \& Methods}

\section{Study site and climate data}

The lucerne fields were located at the Qingyang station on the Loess Plateau, China. It is $107^{\circ} 51^{\prime} \mathrm{E}$ and $35^{\circ} 39^{\prime} \mathrm{N}$. The elevation is $1298 \mathrm{~m}$. Mean annual precipitation (MAP) is between 480 660 mm, and 70\% of MAP majorly falls from July to September. Mean annual temperature (MAT) is $8 \sim 10^{\circ} \mathrm{C}$, and the highest temperature is 39.6 ${ }^{\circ} \mathrm{C}$, the lowest temperature is $-22.4^{\circ} \mathrm{C}$. This area belongs to the rainfed area, and the climate has typical continental characteristics. The majority of the area's soil is Heilu soil(Wang et al., 2015).

\section{Material}

The 11 year old (cultivated in 2002), 8 year old (cultivated in 2005), 5 year old (cultivated in 2008), 4 year old (cultivated in 2009) and 1 year old (cultivated in 2012) samples of lucerne (Medicago sativa Longdong) were selected as the material (until 2012 year). Samples were taken as three cuts (label as $1^{\text {st }}, 2^{\text {nd }}$ and $3^{\text {rd }}$ cuts) at the cutting periods (early flowering stage) in 2012, the dates of sampling were June 6, August 12 and October 24. Then the samples were separated into leaf, stem and root. And the roots were only collected in the soil layer of $0 \sim 30 \mathrm{~cm}$. Next the samples were oven-dried at $105^{\circ} \mathrm{C}$ for $10 \mathrm{~min}$ and then at $80^{\circ} \mathrm{C}$ for at least $48 \mathrm{~h}$ to a constant mass. At this time, the weight of all samples was recorded as biomass. Lastly the samples were smashed into uniform fine powder by a plant-sample mill and sieve mill with a $1 \mathrm{~mm}$ mesh for further measurements. All samples were repeated three times.

\section{Chemical analysis}

The samples, which were sieve milled with a $1 \mathrm{~mm}$ mesh, were weighed to $0.2 \mathrm{~g}$, and added into a digestion tube with $10 \mathrm{~mL} 1.4 \mathrm{~g} / \mathrm{cm}^{3}$ concentrated nitric acid $\left(\mathrm{HNO}_{3}\right)$. Then, the digestion tube was put into a microwave digestion instrument (MARS 240/50, USA), and digested for $1 \mathrm{~h}$. The digestive liquid was put with deionized water into the beaker which was on a $220^{\circ} \mathrm{C}$ hot plate, the volume was about $70 \mathrm{ml}$ in the beaker. Once the liquid was less than $50 \mathrm{~mL}$, the beaker was taken off the hot plate and cooled down naturally. The sample solution was transferred into a $100 \mathrm{ml}$ volumetric flask, and filled to the scale line of $100 \mathrm{~mL}$. Then, all samples were analyzed 
for $\mathrm{Cu}, \mathrm{Fe}, \mathrm{Mn}$ and $\mathrm{Zn}$ by an atomic absorption spectrometer (Thermo fisher iCE 3500, USA) with an airacetylene flame (FA-AAS) at a temperature of $2300{ }^{\circ} \mathrm{C}$ (Khan et al., 2011; Zurawik et al., 2013; Azuma et al., 2016; Li et al., 2020). The yields of microelements were calculated as multiplying lucerne biomass by then contents of microelements.

\section{Data analysis}

Multivariate analysis of variance was performed to assess the effects of cut, age, organ and their interactions on the contents of $\mathrm{Cu}, \mathrm{Fe}, \mathrm{Mn}$ and $\mathrm{Zn}$ in lucerne. Two-way analysis of variance was performed to assess the effects of cut, age and their interaction on the yields of $\mathrm{Cu}, \mathrm{Fe}, \mathrm{Mn}$ and $\mathrm{Zn}$ in lucerne. Differences among the five ages, three cuts or three organs were determined using one-way analysis of variance (ANOVA) and the least significant differences. The liner correlations of the lucerne contents and lucerne yields were analyzed with the model $\mathrm{y}=\mathrm{ax}+\mathrm{b}$. Statistical analyses were performed using SPSS 17.0.

\section{Results}

\section{Effects of cut, age and organ on the contents and yields of $\mathrm{Cu}, \mathrm{Fe}, \mathrm{Mn}$ and $\mathrm{Zn}$ in lucerne}

According to the multivariate analysis, the $\mathrm{Cu}, \mathrm{Fe}, \mathrm{Mn}$ and $\mathrm{Zn}$ contents of lucerne varied significantly as the effects of cut, age, organ and their interactions $(\mathrm{P}<0.05$, Table 1), except the $\mathrm{Cu}$ and $\mathrm{Mn}$ contents under the effect of age $\times$ organ, and the $\mathrm{Zn}$ content under the effect of cut $\times$ organ.

By using two-way analysis, there were significant differences on the $\mathrm{Cu}, \mathrm{Fe}, \mathrm{Mn}$ and $\mathrm{Zn}$ yields of lucerne at the effects of cut, age and their interaction $(\mathrm{P}<0.05$, Table 2$)$, except the Fe yield under the effect of cut $\times$ age. The biomass of whole lucerne plants were also affected significantly by cut, age and their interaction $(\mathrm{P}<0.05$, Table 2).

\section{Cut-effect on the contents and yields of $\mathrm{Cu}, \mathrm{Fe}, \mathrm{Mn}$ and $\mathrm{Zn}$ in whole lucerne}

The biomass of the whole plant increased with the increased cut. And the biomass of the $3^{\text {rd }}$ cut was significantly higher than the biomass of the $1^{\text {st }}$ and $2^{\text {nd }}$ cuts $(\mathrm{P}<0.05$, Figure 1A). There was no significant difference of $\mathrm{Cu}$ content of the whole plant on the cut-effect ( $\mathrm{P}>0.05$, Table 3). The lucerne Fe and Mn contents of $3^{\text {rd }}$ cut were significantly higher than the other cuts $(\mathrm{P}<0.05)$. And lucerne $\mathrm{Zn}$ content of the $2^{\text {nd }}$ cut were significantly lower than the other cuts. The yields of $\mathrm{Cu}, \mathrm{Fe}, \mathrm{Mn}$ and $\mathrm{Zn}$ increased significantly with the increased cuts $(\mathrm{P}<0.05)$.

\section{Age-effect on the contents and yields of $\mathrm{Cu}, \mathrm{Fe}, \mathrm{Mn}$ and $\mathrm{Zn}$ in whole lucerne}

The whole biomass of older lucerne plants (11 and 8 years old) was significantly higher than the biomass in younger ages (5, 4 and 1 years old, $\mathrm{P}<0.05$, Figure 1B). There were no significant difference of $\mathrm{Cu}$ and $\mathrm{Fe}$ contents and yields of the whole lucerne on the age-effect $(\mathrm{P}>0.05$, Table 4). The $\mathrm{Mn}$ and $\mathrm{Zn}$ contents of 1 year old was significantly higher than the other four ages $(\mathrm{P}<0.05)$, while the Mn and $\mathrm{Zn}$ yields decreased first, then increased with the increased ages, and the lowest yields were shown in the 5 year old samples.

\section{Organ-effect on the contents and yields of $\mathrm{Cu}, \mathrm{Fe}, \mathrm{Mn}$ and $\mathrm{Zn}$ in lucerne}

The biomass was highest in the root, higher in the stem and lowest in the leaf $(\mathrm{P}<0.05$, Figure 1C).

$\mathrm{Cu}$ content varied indistinctively among leaf, stem and root $(\mathrm{P}>0.05$, Table 5). Root Fe content was significantly higher than in the leaf and stem $(\mathrm{P}<0.05)$. Leaf $\mathrm{Mn}$ and $\mathrm{Zn}$ contents were significantly higher compared to the 
150

151

152

153

154

155

156

157

158

159

160

161

162

163

164

165

166

167

168

169

170

171

172

173

174

175

176

177

178

179

180

181

182

183

184

185

186

187

188

189

190

root and stem $(\mathrm{P}<0.05)$. The yields of $\mathrm{Cu}, \mathrm{Fe}, \mathrm{Mn}$ and $\mathrm{Zn}$ were significantly higher in the root than in the stem and leaf $(\mathrm{P}<0.05)$.

\section{Compared to the average contents and average yields of $\mathrm{Cu}, \mathrm{Fe}, \mathrm{Mn}$ and $\mathrm{Zn}$ in whole lucerne}

The average contents and average yields were both shown as the $\mathrm{Fe}>\mathrm{Mn}>\mathrm{Zn}>\mathrm{Cu}$ (Table 6). And the average contents and average yields of Fe were significantly higher than the other elements $(\mathrm{P}<0.05)$.

\section{Correlations among the biomass, contents and yields of $\mathrm{Cu}, \mathrm{Fe}, \mathrm{Mn}$, and $\mathrm{Zn}$ in whole lucerne}

The $\mathrm{Cu}$ content increased with the $\mathrm{Zn}$ content, and it positively contributed to the accumulations for the yields of $\mathrm{Cu}$, but it decreased with the increased biomass of the whole plant (Table 7). The Fe content increased with the $\mathrm{Mn}$ and $\mathrm{Zn}$ contents, and it positively contributed to the accumulations on yields of $\mathrm{Fe}, \mathrm{Mn}$ and $\mathrm{Zn}$. The $\mathrm{Mn}$ content increased with the increased $\mathrm{Zn}$ content, and it positively correlated with biomass and the yields of Fe, $\mathrm{Mn}$ and $\mathrm{Zn}$. The $\mathrm{Zn}$ content positively correlated with the yields of $\mathrm{Cu}$ and $\mathrm{Zn}$. Biomass contributed to the yields of $\mathrm{Cu}, \mathrm{Fe}, \mathrm{Mn}$, and $\mathrm{Zn}$. The yields of $\mathrm{Cu}, \mathrm{Fe}, \mathrm{Mn}$ and $\mathrm{Zn}$ are shown as the pairwise correlations.

\section{Discussion}

\section{Age-effect on $\mathrm{Cu}, \mathrm{Fe}, \mathrm{Zn}$ and $\mathrm{Mn}$ in lucerne}

The mean contents of microelements differed intrinsically in different ages and were related with element types in this study. But a common characteristic that the highest contents of $\mathrm{Cu}, \mathrm{Fe}, \mathrm{Mn}$ and $\mathrm{Zn}$ were found in the 1 year old lucerne samples in this study. And Kuang et al. (2007) also found the contents of Fe, Mn and Zn were higher in younger needles of Pinus massoniana. However, the yields of $\mathrm{Cu}, \mathrm{Fe}, \mathrm{Mn}$ and $\mathrm{Zn}$ were highest in the older and/or younger year old stands. Those depended on the contents of the four microelements and the biomass of lucerne. Positive correlations were also found between yields and contents or biomass of lucerne in this study. Those were similar as the carbon and nitrogen accumulation of forest plants (Hooker \& Compton, 2003; Yang \& Luo, 2011). The "reserve emerged" root increased the yield of $\mathrm{Cu}, \mathrm{Fe}, \mathrm{Mn}$ and $\mathrm{Zn}$ as the changing trend of lucerne biomass, although lucerne would be cut the aboveground parts may act as forage many times in one year. Furthermore, the results differ from what was reported in garlic chives where the leaves were removed frequently in an experiment on three year old samples (Zurawik, Jadczak \& Zurawik, 2013). They found leaf Mn content of garlic chives was lowest in the two year old samples than in the one and three year old samples, $\mathrm{Cu}$ and $\mathrm{Zn}$ contents decreased, and Fe contents increased with stand age. The difference may be due to the different species or organs that were sampled.

\section{Cut-effect on $\mathrm{Cu}, \mathrm{Fe}, \mathrm{Zn}$ and Mn in lucerne}

Shoots of lucerne could be cut and removed frequently each year (Maadi, Sakinejad \& Seyedmohammadi, 2013). These may lead to changes in element status and cycling in the lucerne ecosystem (Wang et al., 2014; Wang et al., 2015; Wang et al., 2019), including the contents of lucerne $\mathrm{Cu}, \mathrm{Fe}, \mathrm{Mn}$ and $\mathrm{Zn}$. And the microelements were higher in third cut than first and second cuts in this study, which similarly changed the lucerne biomass of the three cuts (Figure 1A). However the biomass of lucerne would decrease with the increased cuts in previous reports(Tyrolová \& Výborná, 2008; Du et al., 2013). These results differed as the measured biomass was discrepant as whole plant or aboveground. Although the aboveground of lucerne was cut frequently, the root contributed more biomass for the whole plant(Figure 1C), which would accumulate the microelements more in

Peer] reviewing PDF | (2020:08:52102:3:0:NEW 3 Mar 2021) 
this study. This is similar to the elemental accumulation in forest plants (Hooker \& Compton, 2003; Yang \& Luo, 2011). Furthermore, the changeable trend of biomass and the contents of $\mathrm{Cu}, \mathrm{Fe}, \mathrm{Mn}$ and $\mathrm{Zn}$ positively correlated with the yields of $\mathrm{Cu}, \mathrm{Fe}, \mathrm{Mn}$ and $\mathrm{Zn}$ in this study. These led to the highest yields of the four microelements being in the third cut.

\section{Organ-effect on $\mathrm{Cu}, \mathrm{Fe}, \mathrm{Zn}$ and $\mathrm{Mn}$ in lucerne}

Stem and leaf of lucerne were often studied as the utilization for forage in previous research(Tyrolová \& Výborná, 2008; Vystavna et al., 2019). The different percentages from whole plants contributed to the variable nutrient contents (Tyrolová \& Výborná, 2008). The microelement as the mineral element is also changeable in different organs of lucerne (Marković et al., 2009), which has been proven in this study. They all found the contents of leaf $\mathrm{Cu}, \mathrm{Fe}, \mathrm{Mn}$ and $\mathrm{Zn}$ were higher than in the stem, and even higher than in the root (except the Fe contents), which suggested the leaves needed more nutritional support for physiological activity, i.e. photosynthesis etc. Adeniyi \& Olatunji (2019) also proved leaf $\mathrm{Cu}, \mathrm{Fe}, \mathrm{Mn}$ and $\mathrm{Zn}$ were higher than in the stem. Meanwhile, the root contributed more biomass than stem or leaf for the whole plant, the yields of $\mathrm{Cu}, \mathrm{Zn}, \mathrm{Mn}$ and Fe showed the similar results as the biomass of the three organs of lucerne. This is also proven by the correlations between the biomass and the yields of the four microelements in this study.

\section{Correlations among the $\mathrm{Cu}, \mathrm{Fe}, \mathrm{Mn}$, and $\mathrm{Zn}$ in whole lucerne}

Plant $\mathrm{Cu}, \mathrm{Fe}, \mathrm{Mn}$ and $\mathrm{Zn}$ were derived from soil pool, but their contents and yields were variety (Behera et al., 2015; Azuma et al.,2016). Previous literature reported that exogenous $\mathrm{Zn}$ application would enhance $\mathrm{Zn}$ content, but did not influence the contents of $\mathrm{Cu}, \mathrm{Mn}$ and $\mathrm{Fe}$ in maize(Behera et al., 2015). This might mean that there were non-significant correlations between the contents of $\mathrm{Zn}$ and the contents of $\mathrm{Cu}, \mathrm{Mn}$ and $\mathrm{Fe}$ in maize. And the similar results were also found in Polygonatum cyrtonema Hua. (Chen et al., 2020). But now significantly positive correlations were found in lucerne. Perhaps because the species or fertilizer application led to the differences. Furthermore, $\mathrm{Zn}$ application led to more yield of maize, and then enhanced the total $\mathrm{Zn}, \mathrm{Mn}, \mathrm{Cu}$ and Fe uptake (Behera et al., 2015). This is approved by the positive correlations between biomass and yields of $\mathrm{Cu}$, $\mathrm{Zn}, \mathrm{Fe}$ and $\mathrm{Mn}$ in this study.

\section{Conclusions}

The experiment found that the highest contents of $\mathrm{Cu}, \mathrm{Fe}, \mathrm{Mn}$ and $\mathrm{Zn}$ were found in the 1 year old among the five ages, at the $3^{\text {rd }}$ cut, and in the leaf. But the higher yields of $\mathrm{Cu}, \mathrm{Fe}, \mathrm{Mn}$ and $\mathrm{Zn}$ were found in the older ages (11 and 8 years old), at the third cut, and in the root. Furthermore, the contents of microelements and plant biomass contributed significantly positive roles to the yields of microelements in lucerne. Therefore, it is suggested that lucerne microelements are age-, cut- and organ-specific. And the accumulation of microelements would increase even with the frequent mowing of lucerne.

\section{Reference}

1. Adeniyi SA, Olatunji GA. (2019) Evaluation of macro and micro elements in Durio zibethinus Murr and their biological roles on human physiology. Global Scientific Journals, 7(10):1114-1122. 
232

233

234

235

236

237

238

239

240

241

242

243

244

245

246

247

248

249

250

251

252

253

254

255

256

257

258

259

260

261

262

263

264

265

266

267

268

269

270

271

272

2. Afsahi K, Nazari M, Omidi H, Shekari F, Bostani A. (2020) The effects of different methods of zinc application on canola seed yield and oil content. Journal of Plant Nutrition, 43(8):1-10.

3. Akburak S. (2020) Variations of element concentrations in roots of different tree species. Cerne,26(1):118129.

4. Azuma AK, Tomioka R, Takenaka C. (2016) Evaluation of microelement contents in Clethra barbinervis as food for human and animals in contrasting geological areas. Environmental Geochemistry and Health, 38:437-448.

5. Behera SK, Shukla AK, Singh MV, Wanjari RH, Singh P. (2015) Yield and zinc, copper, manganese and iron concentration in maize(Zea Mays L.) grown on vertisol as influenced by zinc application from various zinc fertilizers. Journal of Plant Nutrition, 38(10):1544-1557.

6. Caunii Angela, Probac George, Grozea Ioana, Gaitin Dorin, Samfira Ionel. (2012) Design of optimal solvent for extraction of bio-active ingredients from six varieties of Medicago sativa. Chemistry Central Journal, 6:213

7. Chen Y, Yan YS, Chen SS, Liu HC, Zhao Z. (2020) Content of mineral elements in tubers of Polygonatum cyrtonema Hua. of different ages. Northern Horticulture, (6):115-118.

8. Du SZ, Yang YG, Xin YP, Wang HJ. (2013) Effect of the variety and cutting time on the yield and nutrition level of alfalfa. Acta Ecologiae Animalis Domastici, 34(7):44-48.

9. EISayed HEA, Amen ESA, EIMorsy AH, Tolba MH. (2018) Effects of foliar spraying with microelements and different fertilizer sources on quality and yield of Pisum sativum, L. plant. International Research Journal of Agricultural Science and Soil Science, 2(1):17-24.

10. Hooker TD, Compton JE. (2003) Forest ecosystem carbon and nitrogen accumulation during the first century after agricultural abandonment. Ecology Applications, 13, 299-313.

11. Ierna A, Pellegrino A, Mauro RP, Leonardi C. (2020) Micronutrient foliar fertilization for the biofortification of raw and minimally processed early potatoes. Agronomy, 10(11):1744.

12. Imaran M, Gurmani ZA. (2011) Role of macro and micro nutrients in the plant growth and development. Science, Technology \& Development, 30(3):36-40.

13. Khan KY, Khan MA, Niamat R, Munir M, Fazal H, Mazari P, Seema N, Bashir T, Kanwal A, Ahmed SN. (2011) Element content analysis of plants of genus Ficus using atomic absorption spectrometer. African Journal of Pharmacy and Pharmacology, 5(3):317-321.

14. Kletikova LV, Martynov AN, Fedorov GA, Garkun VI. (2020) The importance of microelements in forming duck liver morphology. IOP Conf. Series: Earth and Environmental Science, 58:042015.

15. Kováčik P, Škarpa P. (2019) Lack of macroelements, microelements and formation of the maize phytomass. Agrochémia, 59:13-16.

16. Kuang YW, Wen AZ, Zhou GY, Liu SZ. (2007) Distribution of elements in needles of Pinus massoniana (Lamb.) was uneven and affected by needle age. Environmental Pollution, 145:730-737.

17. Li CH, Zhu JG, Zeng Q, Liu G. (2020) Changes in microelement availability in a paddy field exposed to long-term atmospheric CO2 enrichment. Journal of Soils and Sediments, 20:2439-2445.

18. Li YS, Huang MB. (2008) Pasture yield and soil water depletion of continuous growing alfalfa in the Loess Plateau of China. Agriculture, Ecosystems and Enviroment, 124: 24-32.

19. Lu JY, Xiong JB, Zhang HS, Tian H, Yang HM, Liu Y. (2020) Effect of water stress on yield, quality and trace element composition of alfalfa. Acta Prataculturae Sinica, 29(8):126-133.

Peer) reviewing PDF | (2020:08:52102:3:0:NEW 3 Mar 2021) 
20. Lukin SV, Selyukova SV, Prazina EA, Chetverikova NS. (2018) A comparative evaluation of macro- and microelement composition of plants of white lupine and soybean. Indo American Journal of Pharmaceutical Sciences,5(6):6133-6137.

21. Maadi B, Sakinejad T, Seyedmohammadi SA. (2013) Effect of the variety and time of cutting on alfalfa (Medicago sativa L.) forage yield. Scientific Journal of Agronomy and Plant Breeding, 1(3):44-50.

22. Marković J, Štrbanović R, Cvetković M, Anđelković B, Živković B. Effects of growth stage on the mineral concentrations in alfalfa (Medicago sativa L.) leaf, stem and the whole plant. Biotechnology in Animal Husbandry, 2009,25(5-6):1225-1231.

23. Muller MH, Poncet C, Prosperi JM, Santoni S, Ronfort J. (2005) Domestication history in the species complex: inferences from nuclear sequence polymorphism. Molecular Ecology:1589-1602.

24. Raeside M, Nie ZN, Behrendt R. (2012) Improving mineral availability for grazing livestock in Australian pasture systems by using plantain and lucerne. Regional Institute Ltd.

25. Skalicka M, Nad P, Hresko SA, Bujnak L. (2016) Micro mineral concentrations of dairy cows in selected areas from Slovak Republic. Journal of Veterinary Science \& Technology, 7(1):1-4.

26. Torabi M, Halim RA, Sinniah UR, Choukan R. (2011) Influence of salinity on the germination of Iranian alfalfa ecotypes. African Journal of Agricultural Research, 6(19):4624-4630.

27. Tyrolová Y, Výborná A. (2008) Effect of the stage of maturity on the leaf percentage of lucerne and the effect of additives on silage characteristics. Czech Journal of Animal Science, 53, 330-335.

28. Vasileva V, Kostov O. (2015) Effect of mineral and organic fertilization on alfalfa forage and soil fertility. Emirates Journal of Food and Agriculture, 27(9):678-686.

29. Vystavna Y, Schmidt SI, Klimenko OE, Plugatar YV, Klimenko Ni, Klimenko NN. (2019) Speciesdependent effect of cover cropping on trace elements and nutrients in vineyard soil and Vitis. Journal of the Science of Food and Agriculture, 100(2):885-890.

30. Wang ZN, Lu JY, Yang HM, Zhang X, Luo CL, Zhao YX. (2014) Resorption of nitrogen, phosphorus and potassium from leaves of lucerne stands of different ages. Plant and Soil, 383:301-312.

31. Wang ZN, Lu JY, Yang M, Yang H, Zhang QP. (2015) Stoichiometric characteristics of carbon, nitrogen, and phosphorus in leaves of differently aged lucerne (Medicago sativa) stands. Frontiers in Plant Science, 6:1062.

32. Wang ZN, Yang M, Lu JY, Yang HM. (2019) Variations in osmo-regulatory and anti-oxidative status and their links with total nitrogen and phosphorus concentrations in lucerne during re-grwoth. Legume Research, 42(1):66-71.

33. Wright IJ, Westoby M. (2003) Nutrient concentration, resorption and lifespan: leaf traits of Australian sclerophyll species. Functional Ecology, 17,10-19.

34. Yang YH, Luo YQ. (2011) Carbon:nitrogen stoichiometry in forest ecosystems during stand development. Global Ecology and Biogeography, 20, 354-361.

35. Zurawik A, Jadczak D, Zurawik P. (2013) Content of macro- and microelements in the yield of garlic chives (Allium tuberosum rottler ex spreng.) according to the plant age. Journal of Elementology, 18(3):521-528. 


\section{Table legends}

312 Table 1 Effects (F-value) of cut, age, organ and their interactions on the contents (mg/kg) of Cu, Fe, $\mathrm{Mn}$ and $\mathrm{Zn}$

313 in lucerne. F-values (P-values) were shown as the results. It was determined by multivariate analysis of variance.

314 The significant difference was at $\mathrm{P}<0.05$.

Table 2 Effects (F-value) of cut, age and their interaction on the yields $\left(\mathrm{mg} / \mathrm{m}^{2}\right)$ of $\mathrm{Cu}, \mathrm{Fe}, \mathrm{Mn}$ and $\mathrm{Zn}$ in lucerne. F-values (P-values) were shown as the results. It was determined by two-way analysis of variance. The significant difference was at $\mathrm{P}<0.05$.

Table 3 The contents and yields of $\mathrm{Cu}, \mathrm{Fe}, \mathrm{Mn}$ and $\mathrm{Zn}$ in the three cuts of whole lucerne. The average \pm standard deviation was shown as the results. The significant difference was determined by one-way ANOVA, it was represented as the different lowercase letters on the contents, and as the different capital letters on the yields $(\mathrm{P}<0.05)$.

Table 4 The contents and yields of $\mathrm{Cu}, \mathrm{Fe}, \mathrm{Mn}$ and $\mathrm{Zn}$ in the five ages of whole lucerne. The average \pm standard deviation was shown as the results. The significant difference was determined by one-way ANOVA, it was represented as the different lowercase letters on the contents, and as the different capital letters on the yields $(\mathrm{P}<0.05)$.

Table 5 The contents and yields of $\mathrm{Cu}, \mathrm{Fe}, \mathrm{Mn}$ and $\mathrm{Zn}$ in the three organs of lucerne. The average \pm standard deviation was shown as the result. The significant difference was determined by one-way ANOVA, and it was represented as the different lowercase letters on the contents, and as the different capital letters on the yields $(\mathrm{P}<0.05)$.

Table 6 The average contents and average yields of $\mathrm{Cu}, \mathrm{Fe}, \mathrm{Mn}$ and $\mathrm{Zn}$ in all cuts and ages. The average \pm standard deviation was shown as the results. The significant difference was determined by one-way ANOVA, it was represented as the different lowercase letters on the contents, and as the different capital letters on the yields $(\mathrm{P}<0.05)$.

Table 7 Significant correlations among the biomass, contents and yields of $\mathrm{Cu}, \mathrm{Fe}, \mathrm{Mn}$ and $\mathrm{Zn}$. The data of all stand ages and cuts were used for analyzing the correlations. "ns" was represented insignificance $(\mathrm{P}>0.05)$. The asterisk “*” and double asterisks “**” represent significant correlations at $\mathrm{P}<0.05$ and $\mathrm{P}<0.01$, respectively.

\section{Figure legend}

Figure 1 The lucerne biomass on cut-effect (A), age-effect (B) and organ-effect (C). The lucerne biomass on cut-effect and age-effect were analyzed with the whole plant. The error bars were the standard deviations. The significant difference was determined by one-way ANOVA, and it was represented as the different lowercase letters. 


\section{Table $\mathbf{1}$ (on next page)}

Effects (F-value) of cut, age, organ and their interactions on the contents $(\mathrm{mg} / \mathrm{kg})$ of $\mathrm{Cu}$, $\mathrm{Fe}, \mathrm{Mn}$ and $\mathrm{Zn}$ in lucerne

F-values (P-values) were shown as the results. It was determined by multivariate analysis of variance. The significant difference was at $\mathrm{P}<0.05$. 
1 Table 1 Effects (F-value) of cut, age, organ and their interactions on the contents ( $\mathrm{mg} / \mathrm{kg}$ ) of Cu, Fe, $\mathrm{Mn}$ and $\mathrm{Zn}$ 2 in lucerne. F-values (P-values) were shown as the results. It was determined by multivariate analysis of variance.

3 The significant difference was at $\mathrm{P}<0.05$.

\begin{tabular}{cccccc}
\hline Treatment & df & $\mathrm{Cu}$ & $\mathrm{Fe}$ & $\mathrm{Mn}$ & $\mathrm{Zn}$ \\
\hline Cut & 2 & 41.793 & 29.133 & 52.622 & 45.489 \\
& & $(\mathrm{P}<0.001)$ & $(\mathrm{P}<0.001)$ & $(\mathrm{P}<0.001)$ & $(\mathrm{P}<0.001)$ \\
Age & 4 & 30.411 & $3.198(\mathrm{P}=0.05)$ & 4.819 & 4.577 \\
& & $(\mathrm{P}<0.001)$ & & $(\mathrm{P}=0.002)$ & $(\mathrm{P}=0.002)$ \\
Organ & 2 & 9.109 & 27.023 & 209.250 & 30.605 \\
& & $(\mathrm{P}<0.001)$ & $(\mathrm{P}<0.001)$ & $(\mathrm{P}<0.001)$ & $(\mathrm{P}<0.001)$ \\
Cut $\times$ Age & 7 & 88.180 & $3.278(\mathrm{P}=0.004)$ & 2.921 & 6.715 \\
& & $(\mathrm{P}<0.001)$ & & $(\mathrm{P}=0.009)$ & $(\mathrm{P}<0.001)$ \\
Cut $\times$ Organ & 4 & 9.132 & $3.805(\mathrm{P}=0.007)$ & 8.724 & 0.807 \\
& & $(\mathrm{P}<0.001)$ & & $(\mathrm{P}<0.001)$ & $(\mathrm{P}=0.524)$ \\
Age $\times$ Organ & 8 & 1.340 & $3.703(\mathrm{P}=0.001)$ & 1.901 & 3.090 \\
& & $(\mathrm{P}=0.235)$ & & $(\mathrm{P}=0.070)$ & $(\mathrm{P}=0.004)$ \\
Cut $\times$ Age $\times$ Organ & 14 & 2.492 & $2.660(\mathrm{P}=0.003)$ & 2.042 & 1.985 \\
& & $(\mathrm{P}=0.005)$ & & $(\mathrm{P}=0.024)$ & $(\mathrm{P}=0.029)$ \\
\hline
\end{tabular}

4

5 


\section{Table 2 (on next page)}

Effects (F-value) of cut, age and their interaction on the yields $\left(\mathrm{mg} / \mathrm{m}^{2}\right)$ of $\mathrm{Cu}, \mathrm{Fe}, \mathrm{Mn}$ and $\mathrm{Zn}$ in lucerne

F-values (P-values) were shown as the results. It was determined by two-way analysis of variance. The significant difference was at $\mathrm{P}<0.05$. 
1 Table 2 Effects (F-value) of cut, age and their interaction on the yields $\left(\mathrm{mg} / \mathrm{m}^{2}\right)$ of $\mathrm{Cu}, \mathrm{Fe}, \mathrm{Mn}$ and $\mathrm{Zn}$ in lucerne.

2 F-values (P-values) were shown as the results. It was determined by two-way analysis of variance. The

3 significant difference was at $\mathrm{P}<0.05$.

\begin{tabular}{ccccccc}
\hline Treatment & df & Biomass & $\mathrm{Cu}$ & $\mathrm{Fe}$ & $\mathrm{Mn}$ & $\mathrm{Zn}$ \\
\hline Cut & 2 & 20.109 & 4.155 & 31.835 & 30.898 & 43.759 \\
& & $(\mathrm{P}<0.001)$ & $(\mathrm{P}=0.026)$ & $(\mathrm{P}<0.001)$ & $(\mathrm{P}<0.001)$ & $(\mathrm{P}<0.001)$ \\
Age & 4 & 12.946 & 2.912 & 4.923 & 7.029 & 10.101 \\
& & $(\mathrm{P}<0.001)$ & $(\mathrm{P}=0.039)$ & $(\mathrm{P}=0.004)$ & $(\mathrm{P}<0.001)$ & $(\mathrm{P}<0.001)$ \\
Cut $\times$ Age & 7 & 2.470 & 4.488 & 1.678 & 2.409 & 6.045 \\
& & $(\mathrm{P}=0.042)$ & $(\mathrm{P}=0.002)$ & $(\mathrm{P}=0.155)$ & $(\mathrm{P}=0.046)$ & $(\mathrm{P}<0.001)$ \\
\hline
\end{tabular}

4 


\section{Table 3 (on next page)}

The contents and yields of $\mathrm{Cu}, \mathrm{Fe}, \mathrm{Mn}$ and $\mathrm{Zn}$ in the three cuts of whole lucerne. The average \pm standard deviation was shown as the results

The significant difference was determined by one-way ANOVA, it was represented as the different lowercase letters on the contents, and as the different capital letters on the yields $(\mathrm{P}<0.05)$. 
1 Table 3 The contents and yields of $\mathrm{Cu}, \mathrm{Fe}, \mathrm{Mn}$ and $\mathrm{Zn}$ in the three cuts of whole lucerne. The average \pm standard 2 deviation was shown as the results. The significant difference was determined by one-way ANOVA, it was represented 3 as the different lowercase letters on the contents, and as the different capital letters on the yields $(\mathrm{P}<0.05)$.

\begin{tabular}{llllll}
\hline & Cut & $\mathrm{Cu}$ & $\mathrm{Fe}$ & $\mathrm{Mn}$ & $\mathrm{Zn}$ \\
\hline \multirow{2}{*}{ Content } & $1^{\text {st }}$ & $15.52 \pm 4.30 \mathrm{a}$ & $600 \pm 139 \mathrm{~b}$ & $30.20 \pm 5.22 \mathrm{~b}$ & $32.19 \pm 6.25 \mathrm{a}$ \\
$(\mathrm{mg} / \mathrm{kg})$ & $2^{\text {nd }}$ & $13.08 \pm 1.14 \mathrm{a}$ & $559 \pm 184 \mathrm{~b}$ & $33.60 \pm 7.150 \mathrm{~b}$ & $23.02 \pm 3.82 \mathrm{~b}$ \\
& $3^{\text {rd }}$ & $14.13 \pm 6.07 \mathrm{a}$ & $1026 \pm 213 \mathrm{a}$ & $46.27 \pm 5.73 \mathrm{a}$ & $37.50 \pm 10.46 \mathrm{a}$ \\
\cline { 2 - 6 } Yield & $1^{\text {st }}$ & $5.65 \pm 2.94 \mathrm{~B}$ & $211 \pm 103 \mathrm{~B}$ & $10.34 \pm 3.98 \mathrm{~B}$ & $11.62 \pm 6.08 \mathrm{~B}$ \\
$\left(\mathrm{mg} / \mathrm{m}^{2}\right)$ & $2^{\text {nd }}$ & $6.18 \pm 2.61 \mathrm{AB}$ & $271 \pm 164 \mathrm{~B}$ & $16.02 \pm 8.55 \mathrm{~B}$ & $10.71 \pm 4.57 \mathrm{~B}$ \\
& $3^{\text {rd }}$ & $8.04 \pm 3.12 \mathrm{~A}$ & $637 \pm 260 \mathrm{~A}$ & $29.29 \pm 11.81 \mathrm{~A}$ & $22.95 \pm 8.26 \mathrm{~A}$ \\
\hline
\end{tabular}

4 


\section{Table 4 (on next page)}

The contents and yields of $\mathrm{Cu}, \mathrm{Fe}, \mathrm{Mn}$ and $\mathrm{Zn}$ in the five ages of whole lucerne. The average \pm standard deviation was shown as the results

The significant difference was determined by one-way ANOVA, it was represented as the different lowercase letters on the contents, and as the different capital letters on the yields $(P<0.05)$ 
1 Table 4 The contents and yields of $\mathrm{Cu}, \mathrm{Fe}, \mathrm{Mn}$ and $\mathrm{Zn}$ in the five ages of whole lucerne. The average \pm standard 2 deviation was shown as the results. The significant difference was determined by one-way ANOVA, it was represented 3 as the different lowercase letters on the contents, and as the different capital letters on the yields $(\mathrm{P}<0.05)$.

\begin{tabular}{llllll}
\hline & Age & $\mathrm{Cu}$ & $\mathrm{Fe}$ & $\mathrm{Mn}$ & $\mathrm{Zn}$ \\
\hline & 11 & $12.57 \pm 3.48 \mathrm{a}$ & $748 \pm 256 \mathrm{a}$ & $38.71 \pm 8.22 \mathrm{ab}$ & $30.12 \pm 4.23 \mathrm{~b}$ \\
Content & 8 & $12.66 \pm 4.16 \mathrm{a}$ & $645 \pm 185 \mathrm{a}$ & $32.11 \pm 7.93 \mathrm{~b}$ & $27.52 \pm 8.89 \mathrm{~b}$ \\
$(\mathrm{mg} / \mathrm{kg})$ & 5 & $14.56 \pm 4.94 \mathrm{a}$ & $783 \pm 426 \mathrm{a}$ & $37.73 \pm 7.69 \mathrm{ab}$ & $29.08 \pm 6.32 \mathrm{~b}$ \\
& 4 & $14.73 \pm 3.82 \mathrm{a}$ & $681 \pm 292 \mathrm{a}$ & $34.98 \pm 11.02 \mathrm{~b}$ & $30.28 \pm 7.80 \mathrm{~b}$ \\
& 1 & $17.26 \pm 4.99 \mathrm{a}$ & $879 \pm 137 \mathrm{a}$ & $44.79 \pm 8.45 \mathrm{a}$ & $40.18 \pm 17.50 \mathrm{a}$ \\
\cline { 2 - 6 } & 11 & $7.24 \pm 3.10 \mathrm{~A}$ & $532 \pm 397 \mathrm{~A}$ & $26.44 \pm 16.66 \mathrm{~A}$ & $19.26 \pm 10.74 \mathrm{~A}$ \\
Yield & 8 & $7.87 \pm 1.52 \mathrm{~A}$ & $448 \pm 221 \mathrm{~A}$ & $22.38 \pm 10.93 \mathrm{AB}$ & $18.16 \pm 7.02 \mathrm{~A}$ \\
$\left(\mathrm{mg} / \mathrm{m}^{2}\right)$ & 5 & $4.94 \pm 2.49 \mathrm{~A}$ & $258 \pm 176 \mathrm{~A}$ & $12.25 \pm 4.32 \mathrm{~B}$ & $9.53 \pm 3.76 \mathrm{~B}$ \\
& 4 & $5.86 \pm 1.36 \mathrm{~A}$ & $294 \pm 188 \mathrm{~A}$ & $14.90 \pm 7.78 \mathrm{AB}$ & $12.36 \pm 4.19 \mathrm{AB}$ \\
& 1 & $8.01 \pm 5.50 \mathrm{~A}$ & $395 \pm 253 \mathrm{~A}$ & $20.02 \pm 12.61 \mathrm{AB}$ & $18.45 \pm 12.55 \mathrm{~A}$ \\
\hline
\end{tabular}

4 


\section{Table 5 (on next page)}

The contents and yields of $\mathrm{Cu}, \mathrm{Fe}, \mathrm{Mn}$ and $\mathrm{Zn}$ in the three organs of lucerne. The average \pm standard deviation was shown as the result

The significant difference was determined by one-way ANOVA, and it was represented as the different lowercase letters on the contents, and as the different capital letters on the yields $(P<0.05)$ 
1 Table 5 The contents and yields of $\mathrm{Cu}, \mathrm{Fe}, \mathrm{Mn}$ and $\mathrm{Zn}$ in the three organs of lucerne. The average \pm standard deviation

2 was shown as the result. The significant difference was determined by one-way ANOVA, and it was represented as

3 the different lowercase letters on the contents, and as the different capital letters on the yields $(\mathrm{P}<0.05)$.

\begin{tabular}{cccccc}
\hline \multicolumn{2}{c}{ Organ } & $\mathrm{Cu}$ & $\mathrm{Fe}$ & $\mathrm{Mn}$ & $\mathrm{Zn}$ \\
\hline \multirow{2}{*}{ Content } & Root & $13.65 \pm 4.56 \mathrm{a}$ & $962 \pm 390 \mathrm{a}$ & $32.99 \pm 10.12 \mathrm{~b}$ & $25.88 \pm 10.90 \mathrm{~b}$ \\
$(\mathrm{mg} / \mathrm{kg})$ & Stem & $14.73 \pm 4.79 \mathrm{a}$ & $578 \pm 299 \mathrm{~b}$ & $27.94 \pm 12.03 \mathrm{~b}$ & $32.38 \pm 13.49 \mathrm{c}$ \\
& Leaf & $15.28 \pm 4.28 \mathrm{a}$ & $605 \pm 518 \mathrm{~b}$ & $65.89 \pm 19.45 \mathrm{a}$ & $39.88 \pm 10.75 \mathrm{a}$ \\
\cline { 2 - 6 } Yield & Root & $2.95 \pm 1.72 \mathrm{~A}$ & $234 \pm 190 \mathrm{~A}$ & $8.34 \pm 7.16 \mathrm{~A}$ & $6.46 \pm 5.77 \mathrm{~A}$ \\
$\left(\mathrm{mg} / \mathrm{m}^{2}\right)$ & Stem & $2.28 \pm 1.01 \mathrm{~B}$ & $93 \pm 70 \mathrm{~B}$ & $4.49 \pm 2.96 \mathrm{~B}$ & $5.04 \pm 2.81 \mathrm{AB}$ \\
& Leaf & $1.46 \pm 1.09 \mathrm{C}$ & $57 \pm 61 \mathrm{~B}$ & $6.31 \pm 4.68 \mathrm{AB}$ & $3.84 \pm 2.99 \mathrm{~B}$ \\
\hline
\end{tabular}

4 


\section{Table 6(on next page)}

The average contents and average yields of $\mathrm{Cu}, \mathrm{Fe}, \mathrm{Mn}$ and $\mathrm{Zn}$ in all cuts and ages

he average \pm standard deviation was shown as the results. The significant difference was determined by one-way ANOVA, it was represented as the different lowercase letters on the contents, and as the different capital letters on the yields $(P<0.05)$. 
1 Table 6 The average contents and average yields of $\mathrm{Cu}, \mathrm{Fe}, \mathrm{Mn}$ and $\mathrm{Zn}$ in all cuts and ages. The average \pm standard 2 deviation was shown as the results. The significant difference was determined by one-way ANOVA, it was represented 3 as the different lowercase letters on the contents, and as the different capital letters on the yields ( $\mathrm{P}<0.05)$.

\begin{tabular}{ccccc}
\hline & $\mathrm{Cu}$ & $\mathrm{Fe}$ & $\mathrm{Mn}$ & $\mathrm{Zn}$ \\
\hline Content $(\mathrm{mg} / \mathrm{kg})$ & $14.15 \pm 4.35 \mathrm{~b}$ & $738 \pm 282 \mathrm{a}$ & $37.15 \pm 9.23 \mathrm{~b}$ & $30.81 \pm 9.59 \mathrm{~b}$ \\
Yield $\left(\mathrm{mg} / \mathrm{m}^{2}\right)$ & $6.69 \pm 3.01 \mathrm{~B}$ & $385 \pm 268 \mathrm{~A}$ & $19.14 \pm 11.87 \mathrm{~B}$ & $15.34 \pm 8.57 \mathrm{~B}$ \\
\hline
\end{tabular}

4 


\section{Table 7 (on next page)}

Significant correlations among the biomass, contents and yields of $\mathrm{Cu}, \mathrm{Fe}, \mathrm{Mn}$ and $\mathrm{Zn}$

The data of all stand ages and cuts were used for analyzing the correlations. "ns" was

represented insignificance $(P>0.05)$. The asterisk "*" and double asterisks "**" represent significant correlations at $\mathrm{P}<0.05$ and $\mathrm{P}<0.01$, respectively. 
1 Table 7 Significant correlations among the biomass, contents and yields of $\mathrm{Cu}, \mathrm{Fe}, \mathrm{Mn}$ and $\mathrm{Zn}$. The data of all stand 2 ages and cuts were used for analyzing the correlations. "ns" was represented insignificance (P>0.05). The asterisk "**" 3 and double asterisks “**” represent significant correlations at $\mathrm{P}<0.05$ and $\mathrm{P}<0.01$, respectively.

\begin{tabular}{|c|c|c|c|c|c|c|c|c|c|c|}
\hline & \multicolumn{4}{|c|}{ Content $(\mathrm{mg} / \mathrm{kg})$} & \multirow{2}{*}{$\begin{array}{c}\text { Biomass } \\
\left(\mathrm{g} / \mathrm{m}^{2}\right)\end{array}$} & \multicolumn{4}{|c|}{ Yield $\left(\mathrm{mg} / \mathrm{m}^{2}\right)$} \\
\hline & & $\mathrm{Cu}$ & $\mathrm{Fe}$ & $\mathrm{Mn}$ & $\mathrm{Zn}$ & & $\mathrm{Cu}$ & $\mathrm{Fe}$ & $\mathrm{Mn}$ & $\mathrm{Zn}$ \\
\hline \multirow{4}{*}{$\begin{array}{l}\text { Content } \\
(\mathrm{mg} / \mathrm{kg})\end{array}$} & $\mathrm{Cu}$ & 1 & ns & ns & $0.626^{* *}$ & $-0.347^{*}$ & $0.420^{* *}$ & ns & ns & $\mathrm{ns}$ \\
\hline & $\mathrm{Fe}$ & & 1 & $0.871^{* *}$ & $0.452^{* *}$ & ns & ns & $0.682^{* *}$ & $0.539^{* *}$ & $0.482^{* *}$ \\
\hline & $\mathrm{Mn}$ & & & 1 & $0.440^{* *}$ & $0.307^{*}$ & ns & $0.658^{* *}$ & $0.623^{* *}$ & $0.513^{* *}$ \\
\hline & $\mathrm{Zn}$ & & & & 1 & ns & $0.418^{* *}$ & ns & ns & $0.537^{* *}$ \\
\hline \multicolumn{2}{|c|}{$\operatorname{Biomass}\left(\mathrm{g} / \mathrm{m}^{2}\right)$} & & & & & 1 & $0.654^{* *}$ & $0.860^{* *}$ & $0.922^{* *}$ & $0.827^{* *}$ \\
\hline \multirow{4}{*}{$\begin{array}{c}\text { Yield } \\
\left(\mathrm{mg} / \mathrm{m}^{2}\right)\end{array}$} & $\mathrm{Cu}$ & & & & & & 1 & $0.605^{* *}$ & $0.637^{* *}$ & $0.772^{* *}$ \\
\hline & $\mathrm{Fe}$ & & & & & & & 1 & $0.965^{* *}$ & $0.868^{* *}$ \\
\hline & $\mathrm{Mn}$ & & & & & & & & 1 & $0.881^{* *}$ \\
\hline & $\mathrm{Zn}$ & & & & & & & & & 1 \\
\hline
\end{tabular}

4 
Figure 1

Figure 1 The lucerne biomass on cut-effect (A), age-effect (B) and organ-effect (C).

The lucerne biomass on cut-effect and age-effect were analyzed with the whole plant. The error bars were the standard deviations. The significant difference was determined by oneway ANOVA, and it was represented as the different lowercase letters.
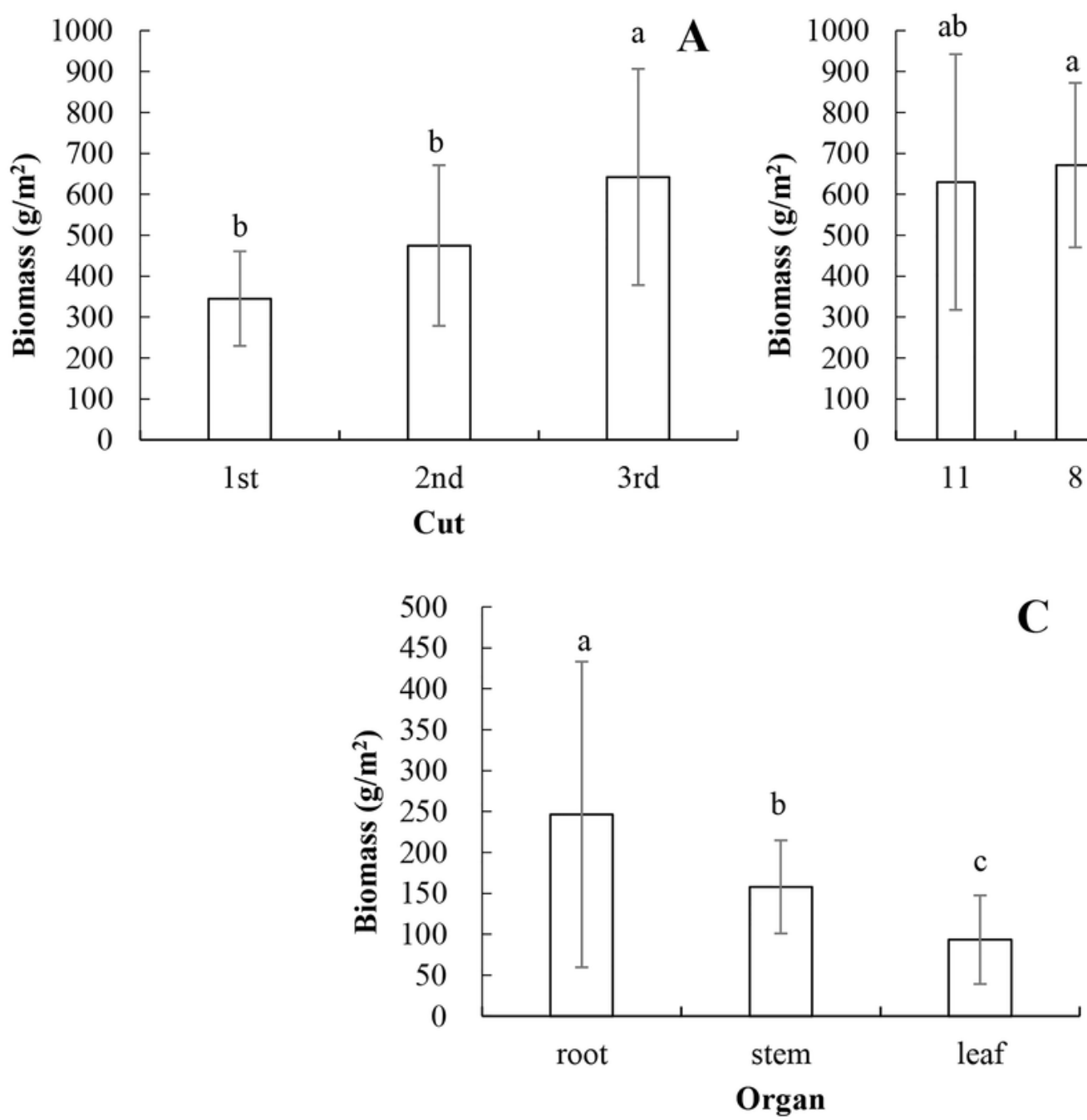

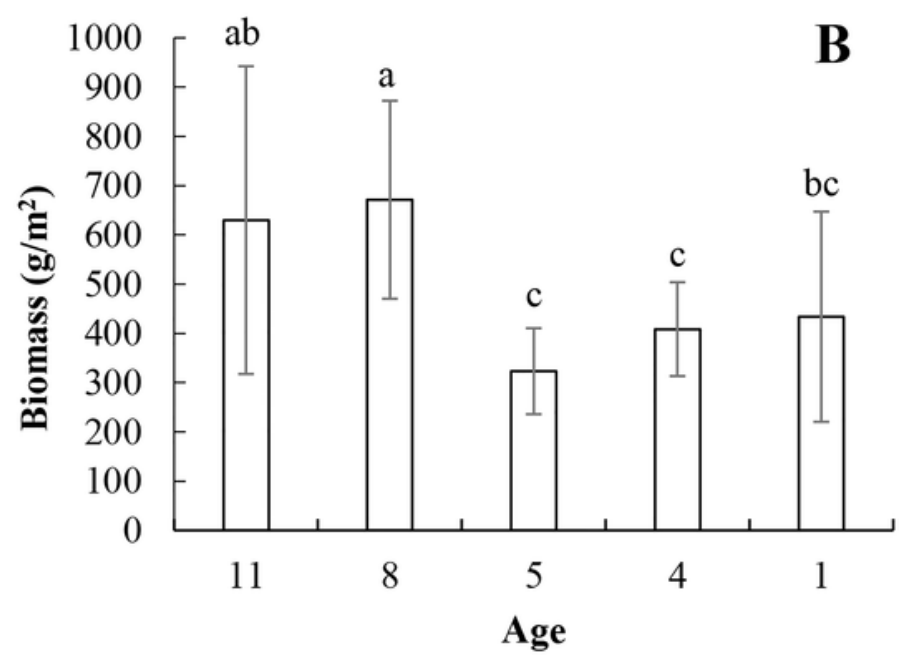

$\mathrm{C}$ 